\title{
Dialogue of Christian Eco-Theology with Hindu Cosmology in the Disruption Era
}

\author{
Daniel Syafaat Siahaan \\ Sekolah Tinggi Agama Kristen Protestan Negeri (STAKPN) Sentani, Papua, Indonesia \\ $<$ danielsyafaatsiahaan@gmail.com>
}

\begin{abstract}
Global citizens of the world are entering a new era, the era of disruption. Terminologically, disruption means the era of chaos or the era of the disturbance. In the Indonesian dictionary, disruption is interpreted as being uprooted from the root. In the era of disruption, nothing is certain and established. The rapid development of information technology has a big influence on this era. This causes the level of local and global competition and competition among individuals or even countries becomes a necessity. Recently the situation of the Americans and Iran has heated up. Indonesia and China also. In a competition, superior-inferior relations become necessary. In such situations, the preservation of nature becomes the most easily ignored, or even sacrificed. For a moment, in competition between individuals or between countries to prove their superiority, nature became the most powerless and inferior. If the balance of nature is disturbed, the most disadvantaged are humans as well as animals. Forest and land fires in Australia are conclusive evidence. When nature is disturbed, humans and animals are the first victims to feel the loss. This issue is the background of the writing of this research. This research seeks to elaborate on the Christian eco-theology notion and to dialogue it with the Hindu cosmology notion. The method used is qualitative research with a comparative study approach. This research is expected to contribute ideas and also enriching the Christian eco-theological dialogue with Hindu cosmology in the era of disruption, in particular concerning the environment.
\end{abstract}

Keywords: Christian eco-theology, Hindu cosmology, era of Disruption.

\section{Introduction}

In academics, the term disruption era is not a new thing these days. Imaginatively, academics can already imagine what and how the era of disruption is. The term disruptive itself was first put forward by Joseph L. Bower and Clayton M. Christensen, in 1995.[1] The notion of disruption in Indonesian and English dictionaries is somewhat different. In the Big Indonesian Dictionary, disruption is 
revoked from the root.[2] Whereas in the Oxford Dictionary, disruption means disturbance or problems which interrupt an event, activity, or process. Whereas the word disrupt means interrupt (an event, activity, or process) by causing a disturbance or problem; drastically alter or destroy the structure of; (of a company or technology) cause a radical change in (an industry or market) by means of innovation.[3] Christensen himself defines disruption as a profitable innovation, not because a company has highly regulated procedures, but because of denial or neglect of what is considered trivial.[4]

Simply stated, Mustoha Iskandar explained the phenomenon of the era of disruption in a public lecture at Lambung Mengkurat University. He explained that the era of disruption was marked by the fall of strong established companies in his day, but was crushed by the presence of newcomers who were often underestimated before.[5] Examples include: Nokia which was once victorious but is now run over by Android, Kodak which is replaced by a Digital Camera and Smartphone to capture images, Bluebird and conventional taxis run over by Uber, Grab and Gojek. The era of disruption is closely related to the Industrial Revolution 4.0.[6] In the Industrial Revolution, cyber technology began to be used in the process of increasing the quantity of production. Likewise in the era of disruption, cyber technology is used by new start-up companies to advertise the products or services offered.

Yan Kalampung argued straightforwardly and strongly about the phenomenon of the Industrial Revolution, which began in the 18th century ago. He argues that the industrial revolution opened the opportunity to give birth to greedy humans, especially towards nature, including Christians. The legitimacy for this is usually taken from the Scriptures, in Genesis 1:28, with emphasis on the words 'dominion' and 'subdue'.[7] This era of disruption associated with the industrial revolution has brought a new civilization of global citizens in all parts of the world. The speed of information technology has a big influence in this era. This causes the level of local and global competition and competition between individuals between countries becomes a necessity. Recently the situation of the Americans and Iran has heated up. Indonesia and China too. In a competition, superior-inferior relations become necessary. In such situations, the preservation of nature becomes the most easily ignored, even sacrificed. For a moment, in competition between individuals and between countries to prove their superiority, nature became the most powerless and inferior. If the balance of nature is disturbed, the most disadvantaged are humans as well as animals. Forest and land fires in Australia are living proof. When nature 
is disturbed, humans and animals are the first victims to feel the loss. In the name of improving the economy or the prestige of a country, nature is first and foremost easily sacrificed.

\section{Research Method}

This research is descriptive qualitative research with a comparative study approach. First of all, researchers elaborate on the thought of Christian eco-theology. In this section, the researcher explains the reasons why this discussion of Christian eco-theology thinking is urgent, especially concerning environmental issues. Then, researchers also elaborated on Hindu cosmological thinking. This section also explains why this discussion of Hindu cosmological thinking is important, along with the reasons for choosing this topic. From there, the researchers then conducted a constructive analytical dialogue on the two thoughts. The dialogue between these two thoughts is egalitarian and constructive towards one another. After dialoguing the two, the researcher then concluded the overall results of this study.

\section{Result and Discussion}

\section{A. Christian Eco-Theology}

It must be humbly acknowledged, that Christian theological ideas tend to give priority to or even to give priority to nature and creation. In Christian theology, human glorification is thicker than nature or creation. In many parts of the Bible also more often talk about God's relationship with humans, and less about the relationship between humans and nature. This was increasingly proven when the industrial revolution occurred. This period opens the opportunity to give birth to greedy humans, especially towards nature, including Christians. The biblical text, in Genesis 1:28, is often used to legitimize dominion over nature with an emphasis on the words 'dominion' and 'subdue' in the text.[8] In Genesis 1, in the process of creating the universe and all its contents, humans are considered as the Crown of Creation. With this in mind, humanity has assumed a superior position compared to nature and other creations.

In 1967, in the Western academic world, there was a great debate about the relationship of theology to the ecological crisis. This happened when Lynn White, a History Professor at the University of California at Los Angeles, published an article entitled "The Historical Roots of Our Ecological Crisis". In his writings, White put forward a theory that explains that the Christian thought model of human dominance over nature has caused environmental destruction.[9] Since then, Catholic and Christian theologians have begun to voice a more friendly theology to nature, known as ecotheology.

Ecology comes from the Greek words oikos (habitat) and logos 
(science). So, ecology is defined as the study of interactions between living things and their environment.[10]

Ecology is understood as the science of all organisms and their habitats.[11] So, eco-theology is the science or discourse that studies the interactions between living things with their environment and relates them to thoughts about God (Theos).

A Catholic priest who is also Professor of Philosophy, Raimundo Panikkar, initiated a thought about the relationship between nature, God and humans with the term cosmotheandrik. Kosmotheandrik itself means cosmos, which is the universe; Theos, namely God; and Anthropos, namely humans. Simply put, this view sees that humans are not separated from the universe, but rather an integrated whole with nature, so that the universe is not an external part of humans themselves.[12] Humans and nature are fellow creatures of God. On the other hand, humans are also part of nature, and both are biological unity. The biblical text in Gen. 2: 7; 3:19, 23; Ps. 90: 3; 103: 14-16 explains that humans are part of nature because they are created from the dust of the earth, and obtain a source of life from nature, and at death will reunite with the soil. Thus, damage to nature can also mean human damage.[13]

In the Christian view, God created humans in His image and image with the aim that humans become rulers over other creations, which He created (Gen.
1:26). The biblical text explains that "God is the owner of the earth and all of its contents" (Ps. 24: 1). But later, "he gave the earth to the sons of men" (Psalm 115: 16). And then, "Thou hast made his power over thy hand made" (Ps. 8: 7). God gives human trust to preserve nature, and $\mathrm{He}$ also holds that trust responsible.[14] Thus, the word "power" and "conquer" in the biblical texts which describe human capabilities to nature is not to exploit nature, but God's delegation to humans to continue the re-creation of nature, not the destruction of nature.

\section{B. Hindu Cosmology}

From the title of this research, some readers may be aware of the different aspects of the discussion of the two religions put forward. In terms of Christian thought, the thought that is highlighted is eco-theology, on the other hand, that is Hindu thought, the subject that is highlighted is cosmology. This is certainly reasonable. Inlay circles as well as Hindu scholars, there is far more to discussing cosmology than theology, especially when talking about the environment. This was recognized by I Ketut Donder. He explained that Hindus, whether lay or academic, usually had philosophical dialogues rather than theological ones. Some Hindu professors (professors) in the field of philosophy are also reluctant to explore Hindu theological discourse because they are considered dogmatic and apologetic. Therefore, 
there is very little Hindu intellectual work in theology. In fact, the phrase Hindu theology is still very foreign to the ears of Hindu scholars.[15] Thus, in this research, I specifically discuss Hindu cosmology, because most of the literature that I get is about it. But it should be noted that, although discussions on the environment among Hindus are more often reviewed from the perspective of cosmological philosophy, there are also theological elements of the commentary that can be further developed.

Cosmology is a part of philosophy and is very close to ontology (general meta-physics), which seeks to find the basic structures and norms for universality.[16] Hindu cosmology is the study of the universe according to Hindu philosophy. In Hinduism, the universe consists of five elements, including earth (solid matter), water (a liquid substance), air (gas substance), fire (plasma), and ether. In general cosmology, the universe takes place without being associated with divine intervention. In contrast to Hindu cosmology, God is placed first and foremost as the 'causa prima' (sangkan paraning numadi) of the universe. [17] From this view, even though this Hindu cosmology is explained from a philosophical perspective, the theological impression does not necessarily fade because God is still positioned as a causa prima.

In addition to thinking about cosmology above, Hindus also have teachings that govern the relationship of God, humans, and the natural environment namely Tri Hita Karana. Literally, Tri Hita Karana can be interpreted as three causes of happiness. The philosophy is that the happiness of life physically and mentally is caused by a balance of three things, including Parhayangan, meaning maintaining a harmonious relationship with the creator, God Almighty; Pawongan, which is maintaining a harmonious relationship with fellow human beings; and Palemahan, which is maintaining a harmonious relationship with the natural environment.[18]

Another interesting thing about the performance of Hindu religious culture is in the form of ceremonies and religious rituals. Most of the ceremonies and rituals of Balinese Hindus present all kinds of trees as a means of the ceremony, though not absolutely. In the history of human civilization, the presence of trees and plants cannot be separated from human life.[19] Archeological evidence explains that there are many carvings in the shape of trees in caves and temple reliefs. In addition, trees are often presented in our holy books as sacred trees.[20]

In the text of the Hindu Scriptures, there are teachings that can be compared to the Christian Scriptures discussed earlier, namely in the Reg Veda. In the Book explained that God entrusted the earth to the wise people, and then God 
responded by giving rain, fresh air, and enough food. In the book of Weda IV IV 25.6, it says:

Aham bhunmi madada, marryyayaham vrstim

Disuse martaya ahamapo, anayam yayasana

Mama devaso and Katamayan

The meaning is: "I give the earth to good people and rain and air for mankind, $\mathrm{O}$ wise people, come to my face with full desire."[21]

\section{Dialogue: Complementing Each Other}

According to Franz Magnis Suseno, there are five types of interreligious dialogue, including the dialogue of life in a basic human community, the dialogue of analysis and contextual ethical reflection, the dialogue of the experience of faith through a basis of inter-faith community (Basic inter-faith Community), dialogue of theology in a basic interfaith community, and joint action dialogue.[22] In this paper, based on the type of dialogue above, the researcher wants to conduct the fourth dialogue model, namely theological dialogue.

Robert J. Schreiter, an intercultural theologian, developed a form of intercultural hermeneutics known as semiotic hermeneutics. Schreiter explained, the process of intercultural communication is needed in order to understand the understanding of faith or other cultures. There are at least three main dimensions of culture, including ideational, performance, and material form. Ideational is a system of meaning in interpreting reality as a guide to the value of community life. Performance is a variety of rituals that follow community members. Material existence is artifacts and symbols that are the source of identities, such as language, food, clothing, music, and architecture. From these three cultural dimensions, Schreiter also explained that there are three core parts in communication, namely: participants (the subject of speakers and listeners), context, and messages. The motivation of the speaker must be as pure as the message. The speaker must understand the context of the listener so that the message can be conveyed openly. Thus, in an egalitarian dialogue process, both the speaker and the listener experience changes as a consequence of communication.[23]

From the two experts above as an introduction, it is clear that researchers want to conduct a theological dialogue by bringing together at least the ideational dimensions of each religion. Robert P. Borrong, a Christian theologian, explains about three understandings of human relations with nature, namely: humans are equal to nature, humans rule nature, or nature rules humans.[24] From the discussion in the previous section of Christian eco-theology, Christianity's teachings are often trapped in the second understanding, namely, humans dominate nature. Thus, there is a way 
for humans to act exploitatively towards nature. On the other hand, in Hinduism, everything in this world including humans is a creation of Ida Sanghyang Widhi. Humans are a microcosm, and the universe is a macrocosm. Therefore, humans as microcosms are part of the world as macrocosms.[25] It is very difficult to find a discussion of cosmology or Hindu theology that places human superiority above creation. In contrast to Christianity, Christian theological discussions are easily directed towards human superiority over nature. However, even so, there are also Christian theologians who view the egalitarian relations of nature and humans. Louis Leahy explained that theologically man and nature are creations, which can be considered the temple of God, and are in a covenant relationship with God. So, if humans destroy nature, then it is the same as breaking the covenant.[26]

Based on this, there is a meeting point for Christian and Hindu religious dialogue, especially when talking about the environment. Both Christians and Hindus believe that the prime cause of all creation, including humans, is God. Thus, humans are equated with nature as God's creation. However, the specificity of humans compared to other creatures is not neglected. Christians and Hindus believe that the Creator gives human trust to continue the re-creation of other creations and is responsible for preserving them. This belief is given not as the legitimacy of human exploitative actions, for its benefit. Because in fact, the destruction of nature as a macrocosm is human damage as well as a microcosm in it.

\section{Conclusion}

The era of disruption is a period of massive and fundamental changes occurring in human life that occur on a global scale. This relates to the emergence of the Industrial Revolution which has entered the fourth stage, 4.0. At this time, the level of competition and productivity of goods and services is very high. In the history of the industrial revolution, a lot of losses felt by nature. To stem this, an effort that can be done is to formulate theological thinking in religion as social capital. In this case, Christian eco-theological thinking and Hindu cosmology can be dialogue to realize the importance of protecting the environment. In both religions, there is a meeting point for dialogue especially concerning human relations and nature. Man and nature are God's creations, the Causa Prima. In the sustainability of creation, God delegates humans as co-creators who are responsible for maintaining other creations. With this rationale in mind, in this era of disruption, it is also important to look at environmental sustainability above economic benefits and human development. Thus, humans as a microcosm need not be harmed if nature as a macrocosm is damaged.[] 


\section{References}

[1] J. L. Bower, and C. M. Christensen. "Disruptive Technologies: Catching the Wave." Harvard Business Review 73, no. 1 (January-February 1995): pp. 43-53.

[2] Kamus Besar Bahasa Indonesia, Offline 1.5.1

[3] Oxford Dictionary of English, Oxford University Press, Version 11.2.546

[4] J. Ohoitimur, "Disrupsi: Tantangan bagi Perkembangan Ilmu Pengetahuan dan Peluang bagi Lembaga Pendidikan Tinggi", in Jurnal Respons Vol. 23 no. 02 (2018) ISSN 08538689, pp. 143-166

[5] M. Iskandar, Disruption Era: Opportunity or Threat bagi Institusi Universitas, bahan Kuliah Umum Program Pascasarjana Universitas Lambung Mengkurat. Banjarmasin, 9 September 2017.

[6] D. S. Siahaan dan Y. K. Labobar, "Consumerist Spirituality: Considering Spirituality in Consumerism Culture in Disruptive Era", in International Conference on Christian and Interreligious Studies 2019 at IAKN Manado, 11-14th December 2019.

[7] Y.O, Kalampung dan W.A. Toad, "Ber-Misi dengan Tuhan dan Alam: Inspirasi dari Kitab Ulangan dan Raimundo Panikkar", in Misi Lintas Budaya (Tomohon: Ukit Press, 2018), pp. 113.

[8] Ibid.

[9] L. White, Jr., "The Historical Roots of Our Ecological Crisis", in Sains 10 March 1967, Vol. 155, No. 3767, DOI: 10.1126 / science.155.3767.1203, pp. 1203-1207.

[10] I G.A.N. Kartika, “Ekologi Lingkungan Hidup dan Pelestariannya Menurut Pandangan Agama Hindu", in Jurnal Widyasrama: Majalah Ilmiah Universitas Dwijandra Denpasar, ISSN No. 0852-7768, Agustus 2013, pp. 8-18.

[11] W. Chang, Moral lingkungan Hidup (Yogyakarta: Kanisius, 2001), pp. 13.

[12] Y.O. Kalampung, "Mempertimbangkan Spiritualitas Ekonomi berdasarkan Intuisi Kosmotheandrik Raimundo Panikkar", in Jurnal Gema Teologika Vol. 1 No. 2 Tahun 2016, pp. 171.

[13] R.P. Borrong, “Teologi Lingkungan Hidup: Perspektif Kristen” in Thomson M.P. Sinaga dkk. (eds.), Pelayan yang Kritis di Alam Demokratis: Buku Pengucapan Syukur 50 tahun Pdt. W.T.P. Simarmata (Tarutung: Kantor Pusat HKBP, 2006), pp. 280.

[14] C. Wright, Hidup Sebagai Umat Allah: Etika Perjanjian Lama (Jakarta: BPK Gunung Mulia, 2007), pp. 67-68.

[15] I K. Donder, "Keesaan Tuhan dan Peta Wilayah Kognitif Teologi Hindu: Kajian Pustaka tentang Pluralitas Konsep Teologi dalam Hindu", in Harmoni: Jurnal Multikultural \& Multireligius Vol. 14 No. 2 (Mei - Agustus 2015) pp. 22-35.

[16] A. Bakker, Kosmologis dan Ekologi: Filsafat Tentang Kosmos sebagai Rumah Tangga Manusia (Yogyakarta: Kanisius, 1995) pp. 5.

[17] I.B.G.Candrawan, "Kosmologis Masyarakat Hindu di Kawasan Tri Danu dalam Pelestarian Lingkungan", in Jurnal Dharmasmrti Vol. XIII Bo. 26 (Oktober 2015), pp. 23-35.

[18] I K. Sudarsana, “Konsep Pelestarian Lingkungan dalam Upacara Tumpek Wariga Sebagai Media Pendidikan Bagi Masyarakat Hindu Bali”, in Religious: Jurnal Studi AgamaAgama dan Lintas Budaya 2, 1 (September 2017); pp.1-7.

[19] Ibid. 
[20] Ibid.

[21] Ibid.

[22] J.B. Banawiratma dan F. M. Suseno, "Dinamika Kerukunan Umat Beragama di Indonesia Tinjauan Kristen Katolik”, in Mursyid Ali, (ed.), Dinamika Kerukunan Hidup Beragama Menurut Perspektif Agama-Agama: Bingkai Teologi Kerukunan Hidup Beragama (Jakarta: Badan Penelitian Pengembangan Agama, 1999), pp. 83-84

[23] K. de Jong, “Teologi (Misi) Interkultural”, in Kees de Jong \& Yusak Tridarmanto (eds.), Teologi dalam Silang Budaya: Menguak Makna Teologi Interkultural serta peranannya Bagi Upaya Berolah Teologi di Tengah-Tengah Pluralisme Masyarakat Indonesia (Yogyakarta: TPK \& DPPPS Fakultas Teologi UKDW, 2015), pp. 39.

[24] R. P. Borrong, Etika Bumi Baru (Jakarta: BPK Gunung Mulia, 2003), pp. 26-40.

[25] I G.A.N. Kartika, "Ekologi Lingkungan Hidup dan Pelestariannya Menurut Pandangan Agama Hindu", in Jurnal Widyasrama: Majalah Ilmiah Universitas Dwijandra Denpasar, ISSN No. 0852-7768, Agustus 2013, pp. 8-18.

[26] L. Leahy, Horison Manusia: Dari Pengetahuan ke Kebijaksanaan (Yogyakarta: Kanisius, 2002), pp. 86. 